\title{
Studies on Legislative Practice of Chinese Government Performance Evaluation
}

\author{
Wu Weidong \\ School of Public Administration, Yan'an University \\ Yan'an, China \\ 576223209@qq.com
}

\author{
Zhang Mengtao \\ School of Public Administration, Yan'an University \\ Yan'an, China \\ 1527233790@qq.com
}

\begin{abstract}
At present, the legislation of performance evaluation has become a key issue in the research of government performance in China. Through focusing on its practices, by using methods of literature analysis and case study, authors in this paper point out the achievements, problems and most importantly the "three steps" strategy in the construction and development of legislation of government performance evaluation in China to promote its development.
\end{abstract}

Keywords-government performance evaluation; legislation practice; legislation development; the "three steps" strategy

\section{LITERATURE REVIEW}

Compared with developed countries, the research on Chinese government performance evaluation starts later. Moreover, there is fewer research on legislation in the field of performance evaluation. Generally speaking, the research on legislation of government performance evaluation includes reviews of present situation, analysis of its necessity, feasibility, approaches and modes, discussion of its framework, and introduction of its achievements abroad and so on.

Considering the research results in recent years, it is not hard to see that legislation of government performance evaluation has attracted attention from scholars. The discussion is more comprehensive, but lack of in-depth analysis. At present, most of the legislation about government performance evaluation in China is based on the experience of foreign legislation. Few scholars have conducted in-depth research on the existing legislative practices of Chinese government performance evaluation. Therefore, authors in this paper analyze the existing legislation practices in China, and reflects on the construction of legislation system of Chinese government performance evaluation.

\section{COMMENTS ON THE LEGISLATIVE PRACTICES OF CHINESE GOVERNMENT PERFORMANCE EVALUATION}

Till now, laws about Chinese government performance evaluation only involve several fields. There isn't an agreed law about government performance evaluation. Although some local governments have already carried out legislative practice, it is still in a spontaneous stage, that badly in need of relevant legislations. Based on Lin Hongchao's classification of legislation on government performance evaluation, this paper analyzes legislative practices from the following four aspects.

\section{A. The Civil Servant Law----Regulating performance evaluation system of individual civil servant}

As one of the laws in the existing legal system of Chinese administrative organization, which was implemented in 2006, the Civil Servant Law consists of 18 chapters with a total of 108 articles. The law expressly stipulates performance evaluation system of civil servant. The fifth chapter (thirtythird to thirty-seventh) introduces the content of civil servant assessment, stressing on the assessment of work performance; stipulates the evaluation mode, including regular assessment and periodical assessment; clarifies the hierarchy and application of assessment results. As for civil servants who are not leaders, periodical assessment is carried out once a year. At first, it requires a summary by individuals according to their responsibilities and relevant requirements; then the leader should give a suggestion on assessment grade after listening to other's opinions; at last, the person in charge or the authorized assessment committee should determine the assessment grade. As for periodical assessment of leaders, the agency-in-charge should handle in accordance with the relevant provisions.

But, the law only stipulate performance evaluation system of individual within civil service. It could not offer thorough legal protection to the government and performance evaluation of civil servants from outside ${ }^{[1]}$. Compared with individual performance evaluation, the performance evaluation legislation of administrative organization is still a virgin land. Whether the Organic Law of the State Council or the Organic Law of the Local People's Congresses and Local People's Governments, there is no substantive provisions about this.

\section{B. The Audit Law---- The core legal basis in carrying out audit on government performance}

The newly revised Audit Law consists of 7chapters with a total of 54 articles. The law clearly stipulates the audit institutions and auditors, responsibilities of audit institutions, audit authority, audit procedures, legal liability and so on. According to article 1 of the newly revised Audit Law in 2006 , the legislative purpose is "to strength the audit supervision of the state, maintain financial and economic order of the country, improve the efficiency of the use of financial funds, promote the construction of a clean government, ensure the healthy development of national economy and society". The terms add "to improve the efficiency of the use of fiscal funds". And the law make provisions that the authenticity, legality and efficiency of the financial revenues and 
expenditures shall carry out audit supervision according to article 2. This two terms can be seen as the core legal basis of carrying out audit of government performance.

But besides that, the Audit Law has no substantive provisions of performance auditing, not even explicitly puts forward the concept of "performance audit". For the first time to establish the framework of government performance audit system in legislation is the Shenzhen Special Economic Zone Audit Supervision Ordinance promulgated by Shenzhen City in 2001. It defines the meaning of performance audit, basic indexes, method, report program and the use of the audit report etc. And it emphasizes that department should base on the deliberations of the Standing Committee of the National People's Congress on the performance audit report to organize budget and determine the institutional setting and staff establishing $^{[2]}$.

C. Measures for the Budget Expenditure Performance Appraisal of Central Government (Trial) ---- A comprehensive evaluation of the central government's budget expenditure performance

From the beginning of 2001, under the auspices of the Ministry of Finance, China has carried out lots of the pilot work for the public expenditure performance evaluation in succession. The central government and some local governments have established the performance evaluation system of public expenditure now. The Measures for the Budget Expenditure Performance Appraisal of Central Government (Trial) consists of 7 chapters with a total of 30 articles. It clearly stipulates the content and method, index, organization and management, working procedures, application of the results of the performance evaluation. The measures are used to comprehensively evaluate the central level's budget expenditure performance. Some provincial and municipal governments have also introduced local regulations and other normative documents for the assessment of the fiscal expenditure performance.

However, the current administrative organization law of the administrative organs of the duty is very simple, abstract, fuzzy, even without a rule, and the administrative organ's annual work plan and long-term development plan are rough as well, they do not specifically cover a variety of project implementation in a given period. Thus, the financial sector in fact cannot evaluate the budget expenditure in these sectors, so we don't know whether the budget expenditure meet the performance goals or not. Moreover, at present, the vast majority of administrative organs do not establish the detailed index which can be used to evaluate the work performance. And the evaluation index mainly depends on the developments of financial departments, but it is almost impossible to accomplish this task only by its own power ${ }^{[3]}$.

D. The Regulations of Harbin Municipal Government Performance Management----The first attempt to legalization of government performance evaluation

The Regulations of Harbin Municipal Government Performance Management consists of 7 chapters with a total of 48 articles. It clearly stipulates the purposes and principles, applicable scope, institutional responsibilities of Harbin municipal government performance management. The Regulation is China's first local government performance evaluation regulation. Its promulgation for local government performance management's standardization and legalization is a major progress and has pioneering value and significance. ${ }^{[4]}$ This system design, through open flow, public participation and focus on communication, makes the performance evaluation function with management consultation and diagnostic function, and achieves the expansion of the traditional government system internal hierarchy evaluation function. It is conducive to promoting the self performance evaluation and the science of the government management. ${ }^{[5]}$

However, as the first legislation, there will inevitably exists some legislative defects, for example, some system design may not be mature enough, and operations are in need of practice; Some of the content and process are so principle that they need to formulate detailed rules; Regulation has no hard performance evaluation plan etc. And the effectiveness of the performance evaluation is weak because of its low level.

\section{E. Comments and anylysis of legislative practice}

From the practice of government performance evaluation in our country, it is not difficult to see that China has made a lot of achievements in the legislation of government performance evaluation. However, it can't be denied that there is still a big gap between the current performance evaluation legislation and the idealized legislation.

\section{1) Achievements}

a) The government performance evaluation legislation guarantees the validity of the performance evaluation. Central or local legislation brings the performance evaluation up to the height of the law, and avoids the Chinese traditional negative impact of the chief executive in the performance evaluation. It can also avoid the randomness of the government performance evaluation.

b) The government performance evaluation legislation ensures the scientificity of performance evaluation. Through the legislation, the government performance evaluation objectives, content, standards and procedures, and so on are determined in the form of legal norms. In the performance evaluation, it can make the evaluation results from multiple factors' interference, and ensure the authenticity and reliability of the results.

c) Successful performance evaluation legislation is used for reference. There are some successful cases in the legislation of government performance evaluation. To a certain extent, it has become an modal for other governments to follow. The result is helpful to the unification of the legislation of the government performance evaluation. However, we should combine it with our own practice, not copy blindly.

d) The legislation of government performance evaluation is integrated with the construction of law-based government. Since 2004, the government proposed to 
comprehensively promote the administration according to law, all the country began to pay attention to the legalization of government performance evaluation, and regarded it as an important part of the rule of the law.

\section{2) Existing problems}

a) Lack of special legislation. There is no special performance evaluation law in our country in terms of the existing legislation. It is more than a local or a field of legislation. The lack of special legislation can easily lead to the local regimes of performance evaluation, and greatly weaken the cooperation ability of performance evaluation; At the same time, there can also appears unavoidably legislative conflict between departments.

b) Lack of operability. The existing legislation in the provisions of the content is more general, and lack of specific implementation details, especially evaluation procedure and evaluation index system of legal norms are seriously lack. It often makes the performance evaluation arbitrary, makes the assessment procedure formulated, or even increases the likeliness of corruption.

c) Lack of matching mechanism. At present, there is no perfect guarantee mechanism for the legislation of the performance evaluation, such as the supervision mechanism, accountability mechanism, incentive mechanism and so on. The phenomenon such as failure to observe the law and lax enforcement often appears in the evaluation, which so seriously damages the authority of the law that the legislation of the performance evaluation has failed to play its true value.

\section{THOUGHTS ON THE LEGISLATION CONCERNING THE GOVERNMENT PERFORMANCE EVALUATION}

The legislation of government performance evaluation is an urgent problem in front of us. In combination with the experience and lessons of our legislative practice, special legislation can be made to regulate the government performance evaluation. This part, with an analysis of the legislation concerning the government performance evaluation, will put forward the "three steps" strategy.

\section{A. The first step: Improving the existing laws and regulations}

1) Improving the local legislation. Firstly, detailing the provisions. Both central and local legislations are generally and ambiguously worded. Therefore, the primary task of improving the legislation is to make specific and feasible provisions on evaluation contents, procedures and methods. A practicable way is to advance the scientificity and authority of the law through colleting ideas online, soliciting public opinions and etc. Secondly, coordinating the local legislation. The local government performance evaluation legislation has so far made great achievements. However, legislative evaluation is only the evaluation activities aiming at the region. Of course, every region has its own characteristics and undoubtedly, something in common with others. Therefore, for their common things, local legislation should integrate them together to facilitate the introduction of specialized performance evaluation law.

2) Improving the central legislation. The central legislation of performance evaluation is distributed in The Budget Law, The Audit Law and The Civil Servant Law. On the current government performance evaluation practice in china, the development of the performance evaluation of the budget expenditures and the performance audit are relatively mature. Both of the objects are pointing to the use of performance of public expenditure. Therefore, the performance evaluation system of the budget expenditure and the government performance audit system should be determined separately in the two laws. ${ }^{[6]}$ In addition, to build a comprehensive evaluation system framework of government performance through the modification of The Civil Service Law, it requires the government to establish a complete management model and index system.

\section{B. The second step: Promoting the reform of the supporting system}

1) Strengthening the information system. The information system construction includes information disclosure and information fidelity. Information disclosure is the premise of effective participation in government performance evaluation. To reinforce the information disclosure system, on the one hand, such means as e-government should be used to enhance the transparency of the government performance information. On the other hand, the publicity system should be improved. The removal of personnel, organization adjustment, changes in policy should be publicized through the window of the government. In addition, the hearing system should be improved and the public opinions be widely solicited to ensure the citizens' satisfaction as to the system installation. The information fidelity system can be improved from three aspects: educate the information providers such values as honesty and trustworthiness, innovate the data statistical quality assurance system, and increase the penalties for information distortion responsibility.

2) Improving the incentive and restraint system. The inefficiency or failure of the performance evaluation legislation is the failure of the incentive and the restraint mechanism, so that it fails to play an effective incentive and restraint part in the government and its civil servants. So the innovation of incentive and restraint mechanism is the key to ensure the effective implementation of performance evaluation. ${ }^{[7]}$ Therefore, in terms of the use of the evaluation results, a full range of incentive mechanism can be designed. For example, the evaluation results and bonuses can be linked, and evaluation results as well as personal ability can be constituted to be the indicators of promotion. In the establishment of the restraint system, resonsibility and penalty mechanism should be improved.

3) Perfecting the responsibility system. The three concrete forms of legal responsibility of the government performance evaluation differ in the aspects of compulsory degree and 
responsibility. There are many defects in the provisions of the current law on the legal liability, including vague language, flexible punishment standard, etc. According to these defects, it is suggested that through the government legislation we should clearly define the legal liability of the government performance evaluation authority, the evaluation subjects (evaluation organizations and experts), the evaluation objects and the users that are commensurate to their powers.

\section{The third step : Introducing The Government Performance Evaluation Law}

Firstly, the State Council drafts and introduces The Government Performance Evaluation Provisional Regulations. However, for a variety of reasons, China began working on the initiation of government performance legislation quite recently, and the legislative department doesn't have much experience in this regard. So the policy making process of The Civil Servant Law can be used as frame of reference to mould the provisional regulations. Provisional regulations should take into consideration the overall mutuality and the experiences gained during the local rulemaking process, and coordinate the relevant laws and regulations, so as to avoid the discord among different levels. Secondly, the National People's Congress enacts The Government Performance Evaluation Law. The law should include the basic framework for government performance evaluation under the Administrative Organization Law. It should also cover the performance evaluation in the field of public expenditure. What's more, it should make the overall provisions for local legislation.

\section{CONCLUSION}

Legislative protection is a key link in establishing and ensuring the authority and independence of performance management. It is also the premise and foundation to carry out government performance evaluation ${ }^{[8]}$. China's government performance evaluation legislation should follow the "three steps" strategy, and advance gradually while adhere to the principles of scientific legislation; It should also focus on the systematic construction of the legislative framework while coordinating the differences between state legislation and the local provisions; the relationships between the Performance Evaluation Law and the related Laws.

\section{References}

[1] Wang Jun, Wang Junying. The Establishment and Advancement of China's Government Performance Evaluation Legislation System[J]. Study Forum, 2010,7,pp.73. (In Chinese)

[2] Yang Qiujun. The Legislative Studies of Government Performance Management. Master's thesis in Party School of the CPC Central Committee in 2013,pp.19-20. (In Chinese)

[3] Wang Jun, Wang Junying. The Establishment and Advancement of China's Government Performance Evaluation Legislation System [J]. Study Forum, 2010,7,pp.74-75. (In Chinese)

[4] Mi Lan. Study on the Legislation of Government Performance Evaluation----Taking Harbin city as an example. Master's thesis in Yanshan University in 2013,pp.27-28. (In Chinese)

[5] Shan Guojun. An Analysis on Local Government Performance Management Legislation----Comment on Legislative Features of the Regulations of Harbin Municipal Government Performance Management[J]. Chinese Administration, 2010,3,pp.31. (In Chinese)

[6] Yang Qiujun. The Legislative Studies of Government Performance Management. Master's thesis in Party School of the CPC Central Committee in 2013,pp.29-32. (In Chinese)

[7] Yan Fang. Research on Institutional Innovation in Government Performance Management in China's Transitional Period. Master's thesis in Zheng Zhou University in 2006,pp.40-42. (In Chinese)

[8] $\mathrm{Hu}$ Shuigen, Jin Lingling. Study on Legislative Issues Concerning China's Government Performance Management and Evaluation [J]. Journal of Public Management, 2007,1,pp.104-106. (In Chinese) 